\title{
Planning and Managing Hill Stations in the Northern Western Ghats
}

\author{
Manasi Karandikar \\ (The author is Founder and Managing partner at Oikos for ecological services, \\ Trustee, Ecological Society, Member - HLMC, Matheran (2012-2014))
}

\begin{abstract}
In a tropical country like India, where the climate is predominantly hot and dry, Hill Stations have served as great retreats for summer vacations. The hill stations are mainly service centers, providing comfortable stay and travel for tourists. Being tourism destinations, the thrust is always given on increasing the number of tourists. In recent past, tourist traffic at hill stations has increased significantly and support infrastructure is being developed for the tourists.

The limiting factors that should have natural control over such development are overlooked. This has caused irreversible damage to the local natural resources, ecology and support systems. Unless a limit on the total number of visitors is enforced at every destination and followed meticulously, it would not be possible to maintain aesthetics, atmosphere, sound infrastructure and ecology for these destinations. Importantly, desires and aspirations of local people with their skill set should be integrated in the overall plan.

In Maharashtra, majority of existing and upcoming hill stations are in the Western Ghats. Considering the ecological fragility of Western Ghats and various life supporting services given by this mountain range, ideally it is not recommended to have any large scale developmental projects. For projects that have already been approved, interventions to reduce current degradation $\mathcal{E}$ restore the near original ecosystem in the area are now urgently necessary. It is important and possible to cater to the needs of local communities and ecosystems and create models with economic benefits in a different way than promoting large scale area development projects. All future progress should be purely in the interest of maintaining ecological integrity and not short-term economic value. This will need more detailed studies and change in policies.

This article uses case studies of two such hill stations, which are also notified ESZ (Ecologically Sensitive Zone) in Maharashtra to illustrate the above considerations. The article also evolves a 'Planning and Management Strategy' that could be useful as foundation for upcoming destinations to integrate the ecological perspective in the process of planning and development.
\end{abstract}

Keywords: Hill stations, Ecology, Western Ghats, River origins, Natural resource management, Sustainability

\section{Preamble}

Prof. Prakash Gole was instrumental in some of the pioneering work in ecology, ornithology and restoration. His understanding about history and economics combined with the landscape, ecology and human activities have put forward 'Landscape-based planning' appropriate for the Indian context. Hill stations by their character depend upon all these factors and their sustainable development will happen only if such factors are considered in totality. It is important to look at the Landscape in a holistic way and evolve Development Plans (DP) without compromising the preservation of ecological order and environment. Modern development must consider ecology as an integral part of the economy.

Prof. Gole was actively involved in preparing a Regional Plan for the Mahabaleshwar - Panchgani Eco-sensitive zone in 1983-84 for the period 1984 to 2001. He also guided a report on the Environmental 
Conservation of the Matheran Plateau. These reports and Prof Gole's teachings is the inspiration behind this article.

\section{Introduction}

The term 'Hill station' is used mainly in tropical countries where a break is needed from regular heat, especially in summer season. The varied topography in India with seven main mountain ranges provides ideal locations at heights suitably higher than plains in almost eleven states. There are about 70-80 old hill stations, situated mostly between altitudes of 1000 to $2500 \mathrm{~m}$, barring a few, which are newly developed.

The hill stations were originally established and developed in British period as their summer capitals, while a few were developed by Indian rulers mainly for leisure. Being visitor centric, these destinations are well connected, have a central 'market area', and many have beautiful water bodies. This is predominantly a service industry with some peculiarities of products, locations or services specifically associated with each such destination.

Hill stations are popular as gateways for holidays mainly because of the aesthetics and natural beauty, situated at higher altitudes, climate, solitude and being away from city crowds. Interestingly this character of being peaceful places is now being substantially disturbed by the inflow of unrestricted number of visitors. Each state of India has a different mountain range and correspondingly a different character for each of its hill towns. In peninsular India, Western Ghats offers a beautiful landscape that

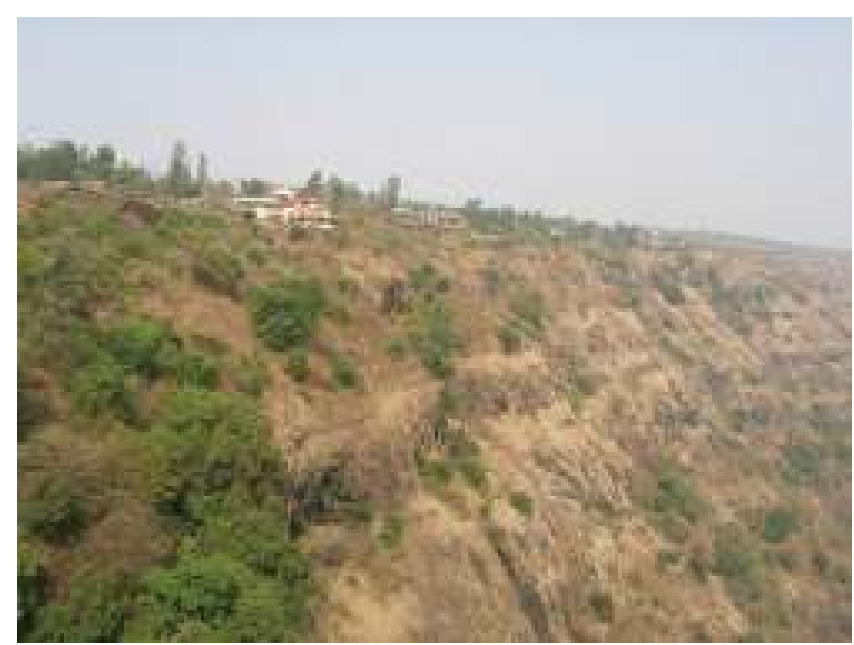

Precipitating hills, plateau forests and tourist resorts at Mahabaleshwar houses many of these destinations. In Maharashtra, all the hill stations except Chikhaldara are located in Sahyadri, which is a part of Western Ghats.

\section{Salient Features}

The two hill stations under consideration in this article, Matheran and Mahabaleshwar-Panchgani region are situated in Western Ghats. Both are notified ESZ and have a strong policy to safeguard the ecological integrity. It must be considered and accepted by all stakeholders that it is the 'aesthetics' and 'climate' at these places that will keep attracting visitors. To ensure this, ecological development of the whole region must be the most important concern.

'Region' in this context means a larger mix use area under notification. Each village or place has a different character according to respective location.

\section{Matheran Hill Station}

Matheran literally means 'forest on the head'. The Government of India vide notification No S.O. 133 (E) dated $4^{\text {th }}$ February 2003 declared Matheran and the surrounding region in the State of Maharashtra as the 'Matheran Eco-sensitive Zone (ESZ)'. This imposed restrictions on industries and developmental activities in the zone.

This Eco-sensitive Zone covers an area of $214.73 \mathrm{sq}$ $\mathrm{km}$ and a $200 \mathrm{~m}$ buffer zone and includes the area of Matheran Municipal Council and its environs, comprising a total area of $251.56 \mathrm{sq} \mathrm{km}$. The Matheran plateau is situated at approximately $760 \mathrm{~m}$ on a mountain top in a hill range separated from the main range of Western Ghats. It is about $48 \mathrm{~km}$ east from the Arabian Sea shore, and about $20 \mathrm{~km}$ away from main Western Ghats range and experiences similar climate as Western Ghats because of the higher elevation than surrounding region. The average annual rainfall is approximately $5000 \mathrm{~mm}$. The region has basalt as the predominant rock while the plateaus are capped with Laterite, a soft, porous rock having average thickness of 12 to $15 \mathrm{~m}$. The plateau has mix of Laterite outcrop and weathered soil profiles. The entire zone comprises hill topography, plateaus, free falls, slopes and deep ravines. Overall it receives high rainfall and has well-drained stream networks. Apart from the streams and rivers as water sources, this region, and more specifically the plateau has numerous springs.

The area is a mix of various forest types changing according to soil, altitude and rainfall, ranging from Moist deciduous to Semi-evergreen. This forest ecosystem supports a variety of flora and fauna 


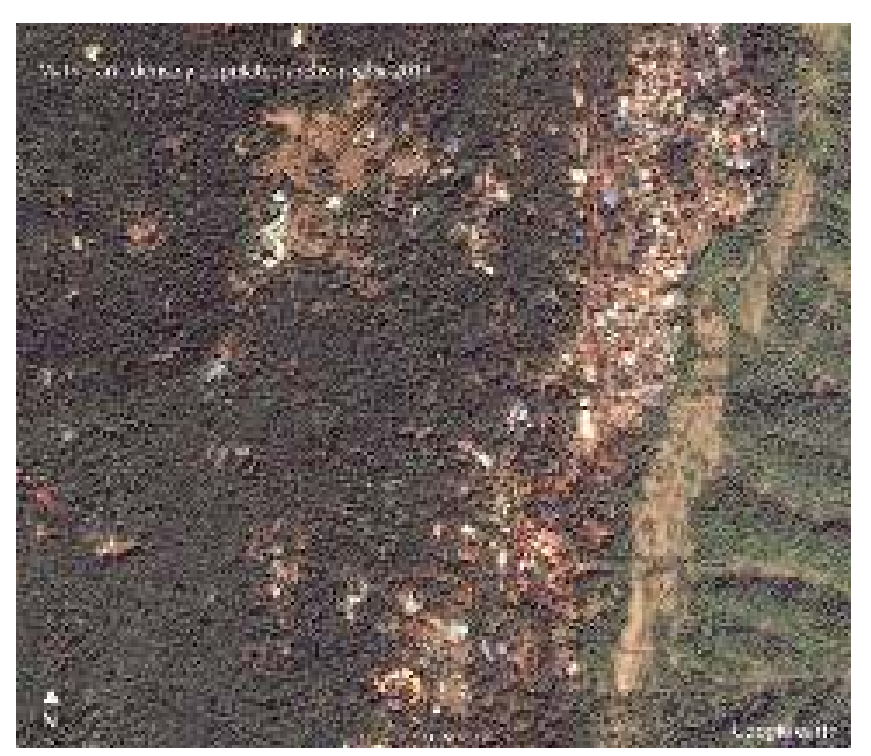

Densely populated areas in Matheran, year 2013

typical of the fragile Western Ghats ecosystem. Owing to all this, the biodiversity is very rich and so is the fragility of this ecosystem.

It is the only hill station where vehicles are not allowed. Most places have to be reached on foot or horseback. With this uniqueness, the area offers a very different experience amongst dense forests, which is the prime factor responsible for attracting visitors. It also has a mini-train which has heritage value.

The history of this hill town traces back to 1850 when it was first discovered by one Mr. Mallet. Until this time it was an isolated hill untouched by human habitation. After its discovery, this destination was developed as a hill resort in a systematic and planned manner. Almost all the present roads were laid out by 1854 and construction of many houses was started that included private houses, churches, infrastructure, etc. Charlotte Lake, the main water source for the resort was completed by 1858 . As the resort started functioning, locals in the surrounding area migrated in search of jobs and settled in the area. By 1900 Matheran was an established 'hill resort' with a bazaar, hotels, houses, church, water supply, etc. The Matheran train started in 1907 that connected it to Neral which made the movement of tourists much easier. Such steady growth was seen with changing political and cultural conditions until 1975. However, the physical structure and architectural character remained quite similar to the original. This period of almost 125 years saw a change from dense tree canopy to a hill town nestled in a forest. After 1980, the area started developing according to the Development
Plan in response to increased tourist flow and corresponding increase in density of built forms. This started changing the character of this Hill Station (Unwalla \& Samant).

In recent years, the plateau has seen uncontrolled growth putting pressure on resources with more extraction, pollution and waste. The local population started increasing after 1960s, and reached up to 5139 people as of 2001 census (Census). This number however decreased to 4393 in 2011. The floating population of tourists continues to increase every year. According to references, the annual floating population increased from 1.67 lakhs in 1991 to 2.51 lakhs in 1999 (Patwardhan). The growing economy through tourism industry refuses to respect the ecological limits necessary to ensure the natural integrity of the area on which it entirely depends.

\section{Mahabaleshwar - Panchgani Region}

The Government of India vide notification S.O.52(E), dated $17^{\text {th }}$ January 2001 declared Mahabaleshwar and the surrounding region in the State of Maharashtra as the 'Mahabaleshwar Panchgani Eco-Sensitive Zone' (ESZ). It is spread over 237.28 sq. $\mathrm{km}$ covering 58 villages.

Unlike Matheran, Mahabaleshwar has been inhabited since $13^{\text {th }}$ century. This also includes the old temple at Kshetra (Old) Mahabaleshwar. There were many additions in later period by successive rulers. In $17^{\text {th }}$ century, Maratha rulers conquered the area and built the fort Pratapgad near Mahabaleshwar. There are records of thick, dense forest cover in Jawali (Jawaliche khore) since Maharaja Shivaji's time. During British rule, Mahabaleshwar was colonized as a summer resort in the early $19^{\text {th }}$ century. General P. Lodwick explored the area in 1824 and the first cottage was built in 1826 by Col. Briggs. After 1828, this area started attracting civilian visitors. This triggered the planned development of public buildings, which was started by the King of Satara. Interestingly, a treaty was signed between British government and the King of Satara to exchange the plateau with two villages in the plains. (Planning Board, July 1984)

Mahabaleshwar-Panchgani is spread on top of the main range of Western Ghats and is one of the highest areas in Sahyadri with highest location at $1436 \mathrm{~m}$ above MSL at Wilson Point and overall altitude of the region at approx $1200 \mathrm{~m}$. The region is wide enough to support a variety of development. The elevation, hilly topography, river valleys, ridges and plateaus with dense forests makes it a unique destination for natural beauty and ecology. The Mahabaleshwar plateau is a 
source region for five major rivers in Maharashtra: Koyna, Krushna, Venna, Savitri and Solashi.

Owing to the elevation, this region has very high rainfall and a cool climate throughout the year. The area in Mahabaleshwar is covered with continuous clouds and heavy downpour in the monsoon season with average annual precipitation of $5900 \mathrm{~mm}$. It has lush semi-evergreen forest. In Panchgani, the conditions are slightly different, it being farther East of the main Western Ghats range. With lower rainfall than Mahabaleshwar of about $1865 \mathrm{~mm}$ average annual, Panchgani has a different forest character, mainly moist deciduous with some semi-evergreen patches. Panchgani, being in rain-shadow of Mahabaleshwar, has less forest-covered areas compared to Mahabaleshwar. This means that the forest character in this whole region changes according to the location, protection, and use by human population.

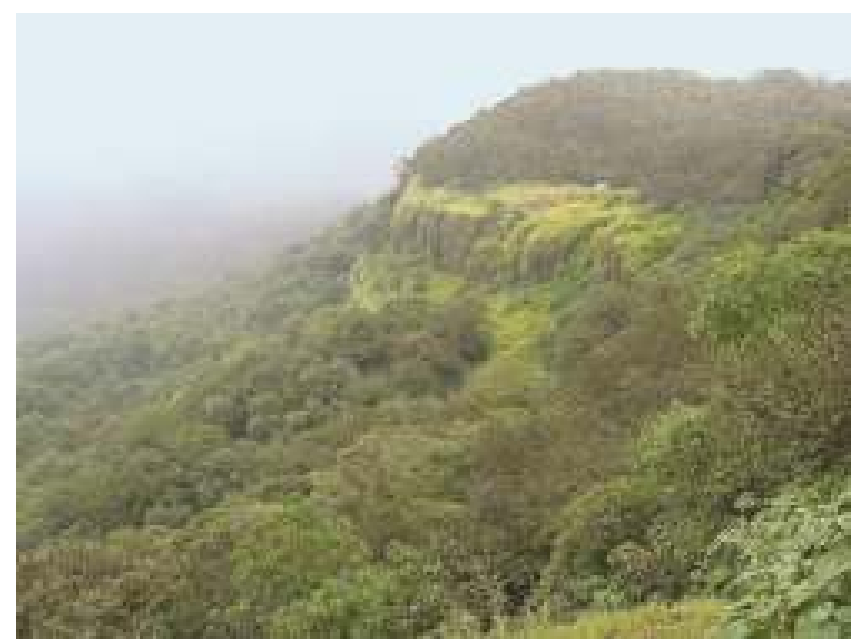

View points - Lodwick point in Mahabaleshwar

Presently this region has two main urban centers namely Mahabaleshwar and Panchgani. There is a steady growth in the resident population over the last few decades, with population of Mahabaleshwar rising from 10564 in 1991 to 13393 in 2011. (Census)

\section{Ecological Value}

Is it worth preserving the ecological value of our hilly areas?

The mountain ranges and hill areas of India have a crucial role to play in determining the climate and physiography of the country and are prime determinants of socio-economic development of plain areas as the rivers have their genesis here. The protection and climatic control they provide have enabled India to sustain its position as an economic power. (Planning Commission, April 2008)

The two major services offered by the Sahyadri mountain range or the Northern Western Ghats to humans are,

- Source of pure water: Major rivers originating in the Sahyadri provide water to plains in peninsular India. A majority of water volume is contributed by Western Ghats region. There are about 50 major dams all along the Western Ghats. Metro cities in Maharashtra i.e. Pune, Mumbai, Nashik survive entirely on the rainfall in Western Ghats.

- Soil resource: Being ideal for soil production, this region which is a narrow $20-25 \mathrm{~km}$ strip provides the soil and essential nutrients for farming in the plains.

Other than this, services provided indirectly by the ecosystem like maintenance of climate, pollination, medicines, food, timber, etc are numerous. It is significant to know and recognize these services at landscape level while developing a plan on the scale of a hill town. Unless the ecological integrity of the landscape as a whole is preserved, the desired effects will not be seen.

\section{Analysis and Problems}

With this brief account of the physical, ecological, and historical setting of two famous hill stations in Maharashtra, let's analyze the regions with respect to various associated problems.

Both Matheran and Mahabaleshwar plateaus are ecologically the most sensitive areas. Being on top and physically separated from the surroundings by precipitating cliffs, they have a very unique ecosystem. The only input it receives is in the form of torrential rains and abundant sunlight. The soil is produced here due to action of various factors by chemical and physical weathering. So it is very important to conserve it at source which is the very basis of why forests on top are so important.

The following points are common for many of the hill stations in Maharashtra including Matheran and Mahabaleshwar. A majority of these destinations are in Western Ghats, which is not just a biodiversity hotspot but also an ecologically sensitive area (BVIEER, October 2010). The topography offers various scenic points and panoramas, overlooking the precipitating cliffs and river valleys below and includes waterfalls, old temples and forts, among other points of interest. More than $50 \%$ of the area is covered with evergreen forest ecosystem supporting 
rich biodiversity, which also represents the fragility of Western Ghats ecosystem. Freshwater lakes have been specifically built as a water source and now serve as major tourist attractions. Numerous springs, many of them perennial, provide water throughout the year for the local population. Such aspects are considered as 'natural heritage'.

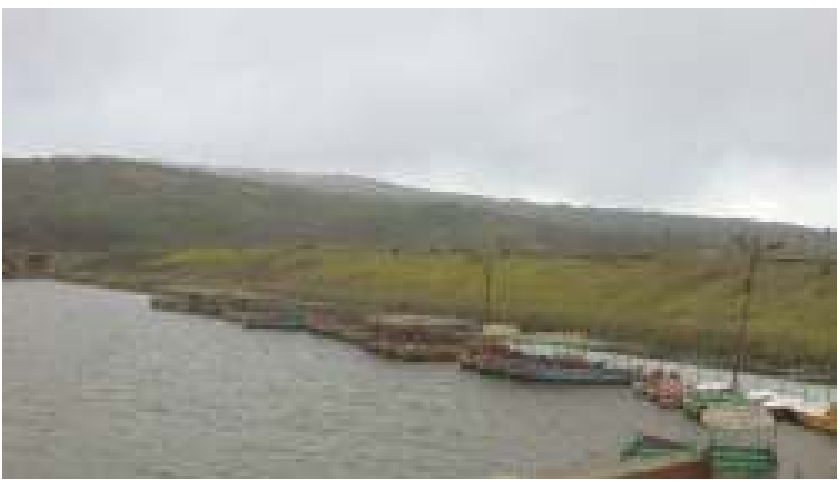

Major source of water - Venna lake, Mahabaleshwar

The 'Land use plan' for both the regions has a mix of private leased plots, residential and commercial areas, gaothan (village centers), hotels, supporting public infrastructure, agriculture and forests. Considering the history, both areas have many sites of archeological importance and thus come under 'Built heritage' worth preserving. Interestingly, these built forms, whether roads, culverts or buildings, were responsive to the local conditions of ecology and climate, and continue to stand valid as 'time tested technologies' even after a century, despite high rainfall and rugged topography. Planning and execution of such built heritage reflect the planner's ability to understand surrounding and design with environmental integrity in mind.

History suggests that hilly regions cannot support large human populations since they have limited plain areas, limited availability of water and limited area for cultivation. The very character of hills cannot support large-scale infrastructure. So the population in hills has always been low with small settlements of one to fifty houses in a 'wadi'. This entirely depends on space and water availability of each settlement site. Springs have been developed by villagers since last few generations for domestic and farm irrigation purposes. The highest spring location in the Koyna valley was found at an altitude of 1,340 $\mathrm{m}$ a.s.l. at Old Mahabaleshwar (Naik, Awasthi, \& Mohan, 2002). In other parts of Western Ghats too settlements have developed around springs.
There are several issues and problems related to Hill Stations that have been studied by various groups and researchers. There is a lot of related data available with individuals, government bodies, NGOs, and academic institutes, though in a fragmented form. Many have also tried to give appropriate solutions considering the ecology of the regions.

Here are a few factors impacting the ecology of the hill station destinations. Some of them are specific to Matheran or Mahabaleshwar, while some are general.

1. Poor implementation of Policy: Even though there are policies and laws to protect ecology, the execution of these regulations is a serious issue. It is seen from many examples and the current situation that rules are not properly followed, creating large scale impacts on surroundings. As an example, it is mandatory to have efficient waste management systems be it Matheran or Mahabaleshwar. However, in Matheran, the sewage created is just let down the cliffs or sent to septic tanks at almost all sources. One must note here that septic tank is not a treatment solution.

2. Increase in the annual number of tourists: The increase in number of tourists has now gone much beyond the 'carrying capacity' of almost all such destinations. The sheer increase in numbers demands more infrastructure and support services. This directly or indirectly damages natural resources, increases pollution and decreases aesthetic value of such places of interest.

3. Change in Land use pattern: More support structures for tourists results in substantial change in land use. Comparison of land use at these hill stations over last few decades shows obvious change from agricultural use to nonagricultural use like holiday homes, second homes, resorts, investment plots, etc. It continues to cause severe degradation of nature and natural resources. Land, once inexpensive, is becoming more and more expensive with the increased purchasing power of the buyer. The attractive financial returns in property development accelerate the squeeze on natural ecosystems even further, thus resulting in a disturbing cycle of degradation.

4. Increase in construction: The tourism industry needs a lot of infrastructure like means of transport (roads, rail, ropeway, air, water, etc), lodging-boarding facilities, entertainment options, food, etc. Creating this support infrastructure for increasing number of tourists 
has an adverse impact on natural surroundings.

5. Real estate development : In recent past, concept of ownership over land and resources in these destinations has increased. This also means that developers bring business, employment, provide investment options to urban population and provide economic growth. This conversion of agricultural land to non-agricultural (NA) is as per law; however it is also converting natural landscape (slopes or agricultural fields and forests) into an urban-scape. It results in removal of biodiversity or at least reducing it substantially, increasing overall temperatures, soil erosion, and more such impacts.

6. Pollution: Both solid and liquid wastes have increased causing permanent damage to the ecosystem and aesthetics. A study conducted in the Charlotte lake catchment in Matheran revealed that the BOD and COD levels of feeder streams were higher as compared to the control sample. BOD of the control sample was $49 \mathrm{mg} / \mathrm{L}$, that of the feeder stream $92 \mathrm{mg} / \mathrm{L}$, that of the lake was $81 \mathrm{mg} / \mathrm{L}$ while the acceptable limit for drinking water is only $30 \mathrm{mg} / \mathrm{L}$. (Ecological Society, January 2007) This clearly indicates introduction of sewage most probably by the resorts in upper stretches. Matheran does not have any system of waste water treatment and all the waste water is either released into forest areas after septic tank overflow or let down the cliffs. The same is the fate of all solid wastes created in Matheran that land up unsorted and untreated in forests, streams, cliff-sides or in the dumping area within forest. The degradable part mixes with soil while the plastics and other non-degradable materials either piles up in surroundings or are burnt, generating the toxic fumes.

7. Mismanagement or violation of rules and regulations: This creates impacts of various intensity at all levels. At both Matheran and Mahabaleshwar breaking of laws and policies is seen by all stakeholders. There are examples like illegal constructions, keeping mules in forest areas at Matheran, extraction of wood, throwing solid wastes, illicit parking, cutting of vegetation, land leveling and many more.

How much is enough is always an elusive question for humans. We humans seem to want 'more' all the time and nature cannot and will not be able fulfill such wants. So, along with analyzing the effects of various wrong actions by humans, one may need to check

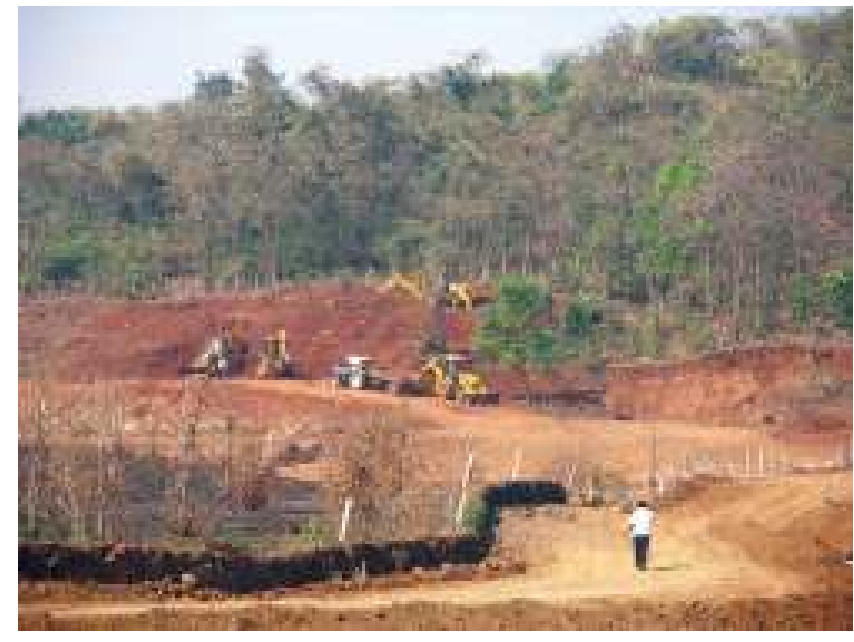

Plot development regardless of topography or nature

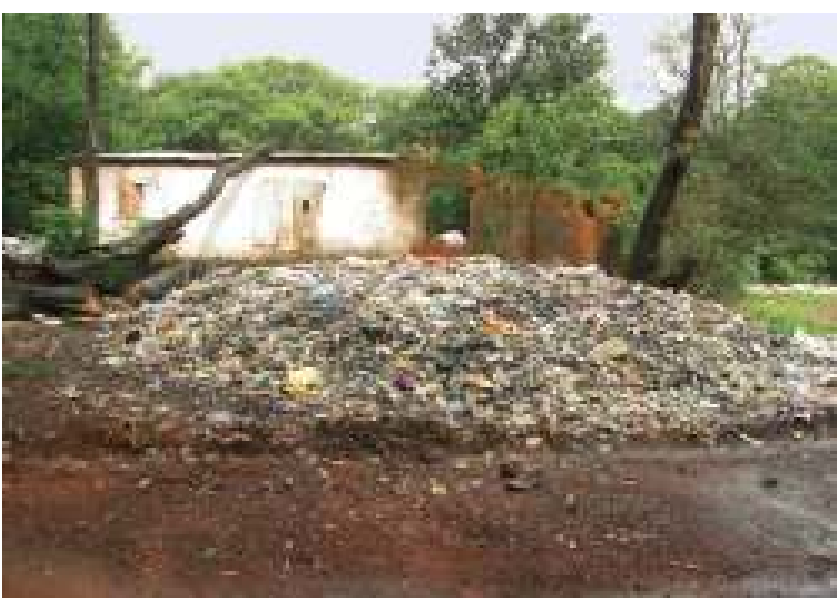

Solid waste dumping at Matheran is within forest and near a natural spring, causing health problems and forest destruction

what is at the root cause. The problems these hill station destinations are facing are due to underlying issues like :

1. Continuously increasing individual wants and self-centered approach of people at large

2. Vested interests of individuals and groups

3. Ineffective implementation of policies

4. Lack of long-term vision that will consider the sustainability for future generations and even the immediate future of present generations

5. Apathy of visitors to follow the rules

6. Sheer increase in population at hill stations and mismanagement leading to decrease in resource availability

7. Lack of civic sense, e.g. keeping these places clean 
These factors have direct or indirect impacts on landscape and ecological integrity. A majority of us humans fail to understand that nature in fact is the very basis of our life. Importance of Hill stations is not just because they are tourist attractions but even more because they are the key sources of 'Natural capital'. A good example is of Mahabaleshwar, which is home to 5 rivers which provide water to almost all of western Maharashtra.

It is also a trend in recent years to open new hill station destinations due to the earlier ones falling out of favor of tourists - primarily on account of overcrowding and degradation. As an example, Lonavala, which was a favorite hill station for people of Pune and Mumbai, has lost its charm due to overdevelopment and saturation. The holiday homes / second home schemes, villas, expressway, resorts have come up in a very haphazard way resulting into a boost in property prices and degrading the natural beauty. Nobody would have imagined traffic jams in Lonavala few decades ago.

In a similar way, Mahabaleshwar has changed its character already and summer seasons witness water shortage and traffic jams. This is leading people to find a new peaceful destinations such as Amboli, which is now becoming a hotspot of tourism and also real estate. If history is what we go by, the fate of Amboli is already sealed. The Government of Maharashtra had also planned to develop 'New Mahabaleshwar'. It is mentioned in their report for 'Tourism and Entertainment' that 'the main source of revenue generation will be through sale of land'. (MIS, 2002)

The hill stations discussed so far are all public

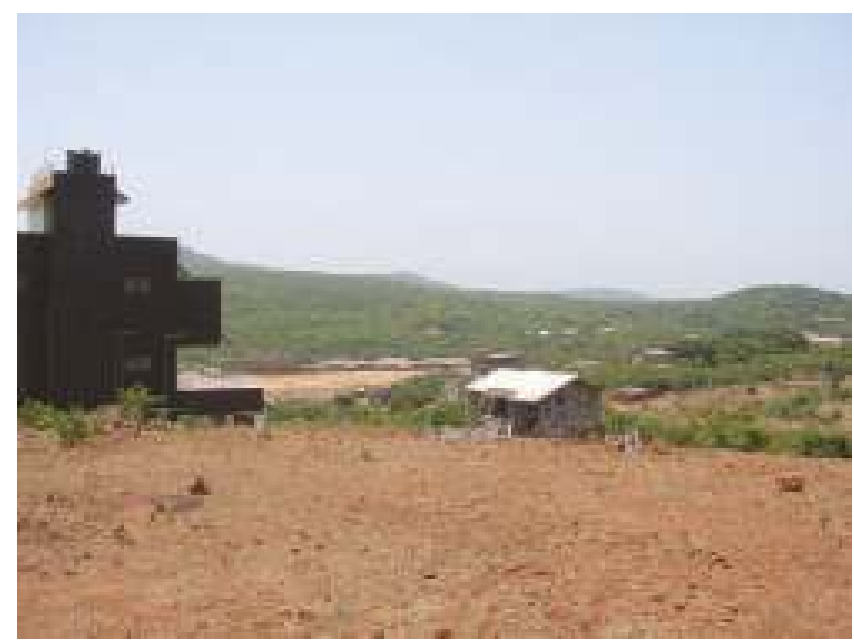

Inappropriate construction \& farm house schemes, Amboli

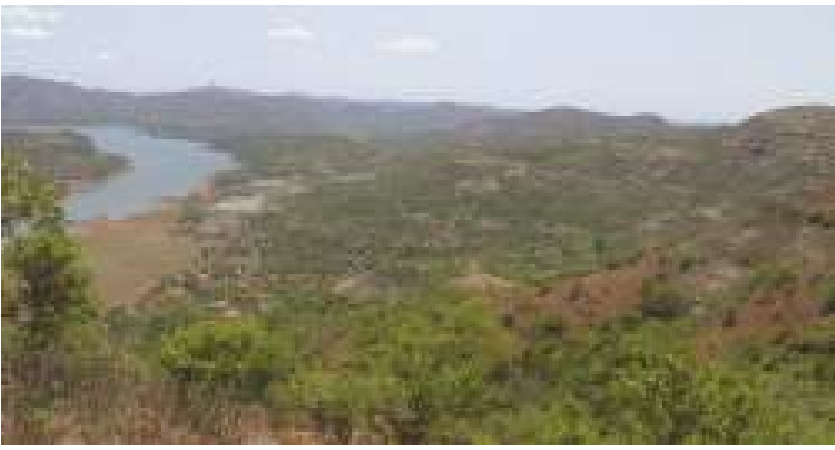

Serene backwaters are the next destinations for new hill stations - Mulshi catchment

destinations. With the 'Hill station policy', notification No. TPS. 1896/1231/CR-123/96/UD-13, dated 3rd September 1996, private developers are able to purchase and develop hill towns. Two such developments are already in place: the Amby valley and Lavasa. These private hill towns aim more at property development for sale, even while they lack the hill station character of catering to the needs of floating population that other hill stations have as public destinations. Lavasa in fact has marketed itself as a new 'city' ideal for business, education, hospitality and retirees.

So, it can well be observed that the tourism on which the economy of hill towns depends in the first place, is putting substantial pressures leading to degradation of the destination. Moreover, marketing a destination as hill station and then rampantly engaging in it's full-scale urban development has become a new business tactic.

The clear reason for all this development is financial potential of tourism and property development.

\section{Ecological Impacts}

Any developmental activity by man will cause modification in the natural landscape. Various activities that take place as support structure of tourism have direct or indirect impact on surrounding landscape and ecology. These activities are carried out as present need, sometimes happen due to negligence or even because of lack of knowledge and understanding of natural resources and processes. Sometimes the impacts of a small activity are aggravated due to topography and climate. Further section proposes to explore how better planning and management can limit such side effect of human actions on nature. Few of the impacts are,

1. Increase in tourism increases extraction of fuel 
wood, being a cheap source of fuel. Even today, majority of cooking and water heating applications use wood as a fuel. This requires felling of trees and removal of dead wood. This slowly changes the vegetation character and degrades the area.

2. Mismanagement keeps on adding to ill-effects of any activity towards development. One such example can be seen at Matheran where majority of transport happens over horseback. Here, it is observed that trees die due to horse urine and dung, affecting a larger area of good forest land. There are more horses than allowed at Matheran which adds to the stresses of mis-management. While not using vehicles at the hill station is a good thing, there is a need to manage the way people move around better in view of queer problems like the one cited above.

3. The road networks hamper movement corridors of fauna. There have been several animal deaths while crossing the road due to collisions with vehicles.

4. Effect on wildlife: There are many unseen, unknown impacts on local biodiversity while few are visible. Monkeys and langurs get attracted to the waste dumping sites for leftover food and animals are known to swallow plastics causing serious injuries. Open dumping also increases stray dog population which starts preying upon small wildlife like bird eggs. Although there are hardly any studies or statistics on this particularly for hill stations, there are many photos, records \& newspaper articles that prove such disturbance.

5. Increase in solid and liquid waste in and around the resorts and public places at hill stations has become an unmanageable problem. Many a time, the solid waste is just dumped down a slope or burnt without any precautions, which is even more dangerous, as it introduces toxins in the air, soil and water. Further impact on the aesthetics of the surroundings is also another significant side effect of growing development on the hill stations.

6. The aquatic life in these mountain streams has hardly been studied in depth, and the impact studies are also lacking. This means one cannot say for certain, what are the impacts associated with such introduction of waste to the streams.

7. A general increase in infrastructure is result of popularity of a particular destination. This directly increases construction and related activities like excavation, quarrying, terracing, leveling and grading. The increase in dust pollution and dust accumulation over the flora is a significant undesirable side effect.

8. Construction companies often take shortcuts like dumping construction wastes in the forested areas. This waste cannot be digested and has a very long life. This causes further deterioration of soil quality.

9. Increased number of vehicles also means need of more space for parking. This needs additional clearing of the natural forest areas. Even then an adequate parking space is not provided in most hill stations. This means illegal parking on road sides and further challenges to traffic movement. Such ongoing growth will eventually lead to losing very large portions of the natural understory to creating parking spaces.

10. Any change in the original topography done without understanding and planning will have adverse impacts on soil by initiating soil erosion.

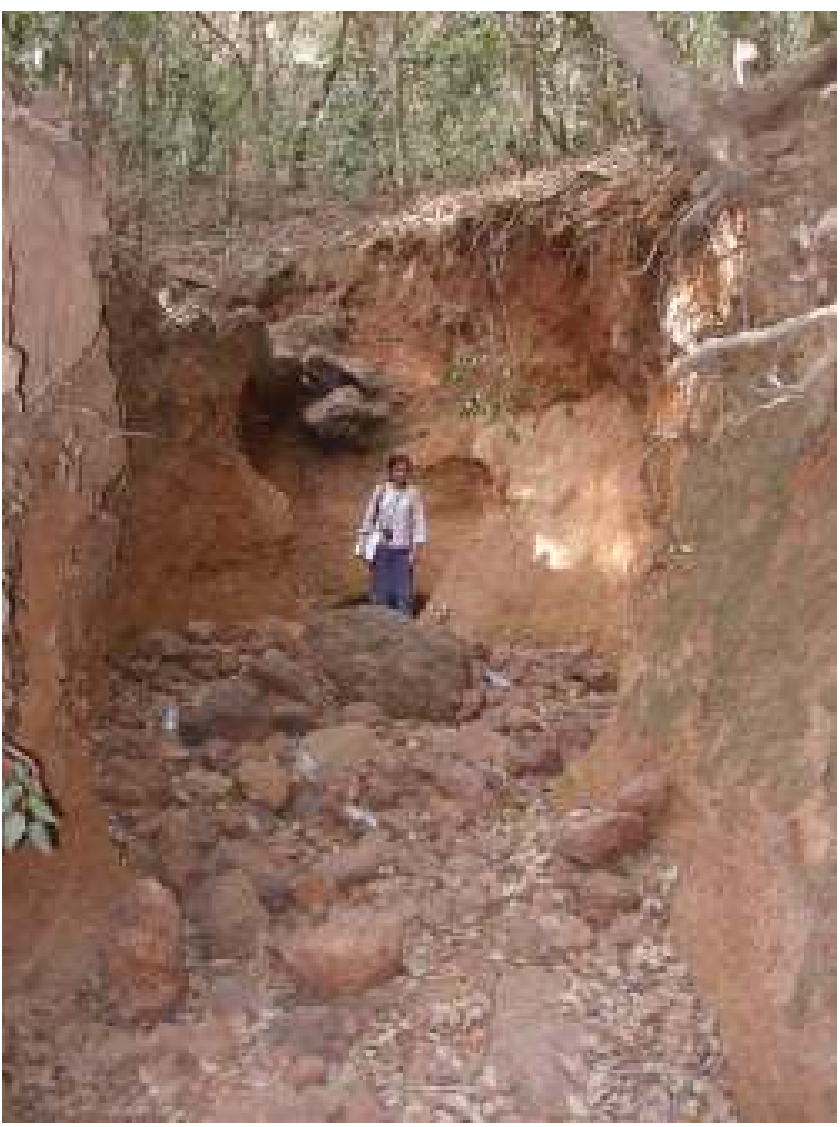

Massive gully formation, soil erosion initiated due to unscientific road work, Matheran 


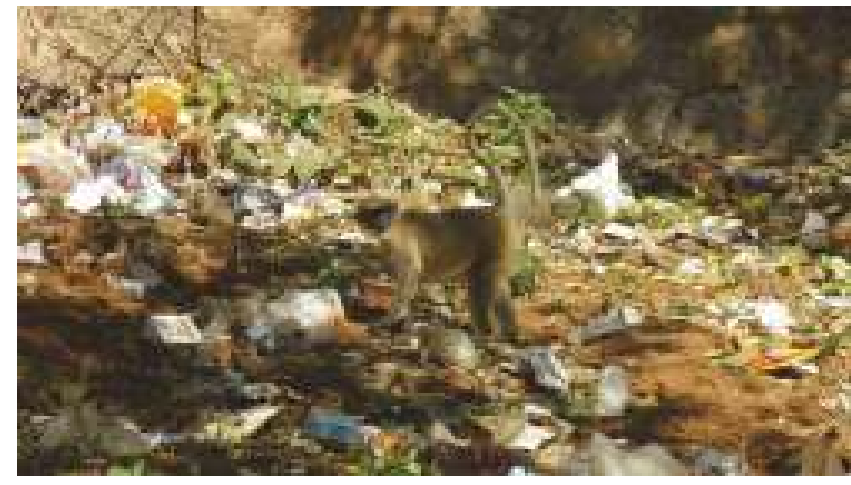

Langurs visiting waste dumping site - not healthy for the wild animals, Mahabaleshwar

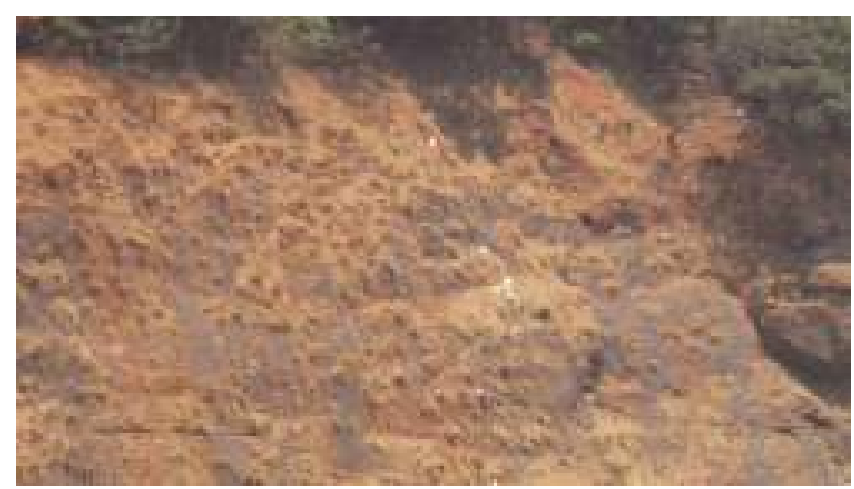

Solid waste thrown over cliffs, Matheran

Matheran has seen massive landslides and associated soil erosion. This is primarily due to roads and rail network, which provide access to the hill station.

11. Change in wildlife behavior is also an important impact that we must be aware of. As an example, monkeys, who really do not need any food from humans, are tempted due to relatively easy access to such food thus changing their food habits.

12. There are many micro level impacts on biodiversity and ecology that go unnoticed as Western Ghats are understudied for biodiversity. Long-term studies that measure such impacts are not undertaken. Apart from just being data deficient, it is quite hard to go through the benchmarking process as the so called developmental activities proceed at fast pace. This means that the area and biodiversity keeps on changing continuously.

The question is can we manage these hill stations better from the development perspective and retain the natural beauty of these areas? Can we maintain through sound management principles, charm and peace in all such destinations? It seems a distinct possibility if we base our planning on aspects of Landscape and 'Resource availability'. It is tantamount, that the rules for development and use of facilities and infrastructure are indeed followed strictly. Could such hill stations be economically viable, while maintaining the ecological integrity of the area? Even though this is not the subject to be covered in the current scope, it is certainly necessary to initiate studies on how to maintain 'ecological integrity' with 'economic benefits'.

\section{Planning and Management}

With the understanding that maintaining the ecological value will ensure healthy hill station communities, let's see what are the various planning and management considerations for existing or new hill stations.

The most prominent difference in old hill stations and new hill stations is the older ones were settled by clearing primary forests, while the new ones are being developed over secondary forests and open scrub areas.

Basic planning of any such destination must consider various factors of ecology, its spatial distribution, opportunities created by nature and limitations imposed by the terrain. The development responsive to such aspects will then have much lower impact on nature.

Each destination has a 'carrying capacity' that needs to be carefully considered while preparing any developmental guideline for such area. This carrying capacity depends upon a number of factors; the first two key factors are 'water' and 'space' availability. Apart from this, it is also important to consider aspects like support infrastructure (mainly roads, public utilities, other essential facilities), maintenance of aesthetics, waste handling capacity, pressure on resources and ecology. All these factors together will derive the number of resident population, number of tourists per year and respective support structure. Also, the type of tourism and visitor attractions needs to be responsive to overall character of the destination.

\section{Management and Policy guidelines for ecological conservation}

\section{Policy framework}

A review of existing policies shows some contradictions in objectives, specifically for Western Ghats. E.g. there is a guideline for 'Catchment area 
treatment' framed by the Central government for irrigation projects, which safeguards the dam life by controlling soil erosion in catchment. It is mandatory for the project proponent or respective government agency like Forest Department to submit a plan along with the total project plan for the dams (Badrinath Forest Division). But with policies towards development like the Hill Station policy which in same dam catchments increases development \& induces soil erosion.

Fragile biodiversity is found in protected areas (PAs) as well as outside on private lands. So it is important to frame a set of guidelines for areas outside PAs where land development over privately owned lands is taking place rapidly. These guidelines should focus on ecology \& biodiversity conservation but should not impose them on the local communities. If innovative ways of 'pay-back for conservation' like green cess, waiver in income tax, use of CSR funds, etc are developed then people will willingly participate in conservation. But these pay-back options should be available to local, non-polluting, non-destructive, small-scale proposals than large-scale area development projects. Some organizations are already initiating such mechanisms on a small scale; they must be supported by the Government.

Even in the EIA clearance procedure, there are many aspects that need improvements. The Government should proactively impose rules to conserve nature while giving various permissions to projects. It is also necessary to review the minimum area criteria for developmental projects like farm houses specifically in Western Ghats. Otherwise a large number of small units will still end up degrading more than a single large-scale development. There are examples of such small schemes spread over an area of 20 to 100 acres happening in Mulshi catchment near Pune, Maharashtra, where NA plots of $2000 \mathrm{sq} \mathrm{ft}$ size are sold as investment plots with all amenities of roads, water, and electricity. Such development patterns have negative impact on existing ecosystems and do not add in any way towards betterment of environment of the region.

Drafting more comprehensive policies will require detailed understanding of ecosystem dynamics, interrelation with humans, current ecological status, restoration potential, use of restored landscape for fulfillment of human needs and its tourism value.

Sometimes it is also important to understand the local nuances related to hill stations. E.g. the residents at Matheran hardly appreciate it being a pedestrian- only hill station. For the locals, it is really cumbersome to live in an area which cannot be reached on motorized vehicles while watching a world with modern amenities and urban aspirations. This makes us question why have permanent populations in areas like Matheran where the policy demands protection of environment and ecological integrity while the ground conditions are totally opposite. Such flaws in policy and ground realities are difficult to eliminate quickly. But it is essential to re-think and take a position if the natural ambience at Matheran needs to be maintained for attracting tourists.

\section{Existing Hill Stations}

Following current policies and regulations and forming new regulations essential for conservation will ensure healthy environment for existing Hill stations.

1. Control on number of tourists per day: This will also mean that there has to be a tourism management plan in function with an aim to distribute number of tourists evenly over the year. Proper planning will not reduce the economic benefit created by tourist inflow and will reduce the stress on environment.

2. Efficient transport management: At Matheran, which is a special case being the only hill station that is vehicle free, private cars are parked at Dasturi (the last point where vehicles are allowed). The existing parking plan is not sufficient for ever-growing numbers of cars. Also the parking land is under the purview of forest department being a forest land. Many have suggested alternatives to this like ropeway, parking at Neral, shuttle service to Dasturi, use of goods trains, etc which will reduce the sprawl of in parking forest areas. A goods train is now running within Matheran which has reduced pressure on Mules and hand-pulled carts and is proving beneficial for local residents.

3. Provision of alternative fuel sources. It is observed that fuel wood extraction for serving local as well as floating population is high at any hill station. This keeps on deteriorating forest areas as well as the degraded areas for extraction of fuel wood. If fuel wood is a basic need, then a large scale fuel plantation on open lands should be undertaken to reduce pressure on existing forests. Also other appropriate fuel sources like biogas from solid waste or biomass, improved chulha, etc must be considered.

4. The government DP (Development Plans) should 
be responsive to the ecological factors and keep the aesthetics intact. As an example, in the proposed DP of Matheran region, the most sensitive Matheran plateau is shown as 'Urbanisable zone' which is a contradiction to the above-stated need of protection to existing fragile ecosystem from developmental activities.

5. Environment friendly techniques of use, reuse, and recycle for water sources and use of local water resources.

a. Hill stations in the Western Ghats region receive very high rainfall (ranging from 3000 to $6000 \mathrm{~mm}$ average annual) so water is abundant during the four months of monsoon and then there is acute water shortage during summer. So there has to be a multi-source use method for catering to the fresh water needs of the entire year that will be based on seasonal variations in water availability and use. For example, direct use of rainwater is possible during monsoon with small storage devices at multiple locations. Similarly, rainwater can be stored in larger structures that will be useful for winter, and finally for the summer season other centralized sources like lakes, rivers can be tapped. Such systems will require careful planning and awareness amongst users.

b. Encouragement to use local water sources and improvement in the quality and sustainability of these sources must be undertaken to reduce water crunch in summer seasons. Many times it is seen that during hill station development, existing open wells or springs are totally neglected and lost in the process. E.g. there are many ancient wells and perennial springs in Mahabaleshwar-Panchgani region. These were harvested and used by the villages. Even the Old Mahabaleshwar Temple where 7 rivers are believed to originate was based on perennial springs. But new uncontrolled water guzzling developments of resorts in this area have depleted these natural resources. There are many such examples in the region e.g. spring in Godawali village in the vicinity of Panchgani table land where over extraction of ground water have led to zero discharge from the old spring on which the village and surrounding farming was dependent. Protection and management of natural springs and streams is necessary for future water security and must be taken as priority for the planning process (Kulkarni \& Buono, 2014). Spring and stream development should also consider the needs of local biodiversity.

c. Generally as high as $90 \%$ of the fresh water is released as waste water. Re-use of treated waste water for uses other than drinking will reduce the need of fresh water to a great extent.

6. Nature-based, ethical tourism and local participation is perhaps the only sustainable way for management of hill stations and it makes sure the benefits of development will reach local people. Both have different advantages but will ultimately safeguard the ecology. Due to the direct benefit to local community, it will encourage them to conserve their surroundings as the base for attracting tourists. It is possible to encourage participation of local people through home stays, hotels, restaurants, taxi, etc. In fact, if more of the tourist share is handled by home stays, the ecological footprint related to hotels and restaurants will be reduced. A good example is set by Choukul village in Amboli where villagers have started home stays for visitors on a small scale.

7. There should be guidelines for appropriate types of entertainment. For example, having night clubs, pubs and bars, casinos, and water parks at hill stations will surely change the culture, type of tourists and indirect use of resources which is totally opposite to the ideal character of development at any hill station. Instead, entertainment like nature trails, food joints, boating, horse riding, etc which is less impacting on character and ecology of the region should be promoted.

8. Tourist information and awareness is a very effective tool for better management. Along with the tourists, education of residents, owners and even the property developers is required in such sensitive areas. An 'Awareness Program' considering aspects like ecology, landscape, biodiversity, cleanliness, waste management, and land management will prove to be useful in management.

9. Aesthetics is important but unfortunately there are hardly any guidelines on the character of buildings, signage, roads, and stalls. Recently, the Matheran Municipal Council developed a manual specifying do's and don'ts for street furniture, signage, compound walls, etc which is a very positive move and it was also supported by the Heritage Committee. This manual is for reference by anyone who wishes to develop 
property at Matheran. Similarly, the Draft Regional plan for Mahabaleshwar-Panchgani region, published in 1984, referred to the 'Removal of haphazard and ugly signage' and about the need for the local unregulated stalls to be well-placed and better-designed. (Planning Board, July 1984)

10. Control of vehicular traffic has been widely discussed. It must be noted here that there are very few flat areas in the hilly terrain, so transportation problems must be addressed with a proper plan. A 'Public Movement Plan' needs to be developed for all the hill stations to avoid traffic jams. Vehicular traffic not only puts pressure on roads and add to pollution but also destroys undergrowth of forest areas for the sake of parking space. Parking is not considered a necessity during design stage at any of the destinations. Thus, unofficial parking space is posing a serious threat to forest ecosystem around scenic view points, in hotels or restaurants and in public attraction places. The ideal path, of course, is to eliminate or minimize transportation as much as possible in these areas.

11. There are people who continue with agriculture and horticulture for cereals, fruits, vegetables, etc in the Hill Station areas. Some regions have their own specialty e.g. Mahabaleshwar is famous for it's strawberries. But in the recent past, people have started using plastic mulches for growing strawberry and impact of general apathy of farmers to manage the wastes created after use or harvest is seen in fields, along roads and trees, even on overhead electric cables. One can notice black polythene fragments lying and being blown away by strong winds in most parts of Mahabaleshwar. If this system of cultivation is managed with environmentally sustainable practices then the destinations could be self sufficient in terms of food. It is necessary to develop organic farming that is local and leverages biodiversity. This will reduce the pollution and negative health effects due to modern farming that uses harmful chemicals such as fertilizers and pesticides.

12. It is known that hill stations have rich forests. In 1983, the Mahabaleshwar region had $52 \%$ forest cover as per the land-use analysis. Scientific 'Forest Area Management Plans' must be developed in consultation with experts and local forest departments. In such plans, restoration of degraded areas, protection of existing high quality forest patches, plantation of native species, etc must be considered. People at all levels, from local municipalities to visitors, need to be made aware for the need and ways to conserve forests.

13. The awareness for using only native plants for all aspects of plantation must be adopted and widely spread amongst the hill station community. A good example of wrong species selection is seen at Mahabaleshwar where the council has planted Bougainvillea and Datura arborea right at the edge of forests along the roads. The question is will this enhance beauty of already existing dense forest or suppress the beauty and growth of the forest as Bougainvillea is known to spread wildly over trees. Effects of non-native species are already seen in Mahabaleshwar forests and road sides. Plants planted in gardens e.g. Datura spp or as fences like Duranta spp can become invasive over a period of time. The herb Ageratina adenophora has become invasive and replaced the original forest shrub wayti (Thelepaepele spp). There are many such examples where various stakeholders, including government departments are not aware of problems of introduction of nonnative species and keep on planting such trees and shrubs for all sorts of plantation needs. So awareness of preferring the native, beautiful plant varieties for any plantation or gardening is essential and required for preservation of ecological order.

\section{Proposed new destinations}

With upcoming large-scale, hill station type developments in line, it is important to take a fresh approach for new destinations.

To start with, any new 'hill station' project, proposed in our ecologically sensitive areas like Western Ghats, should be simply re-evaluated whether it is even necessary. Such projects provide short-term pleasures like bungalows, hotels, and tourism for a wealthy few among us. In the process, the entire long-term future of a fragile ecosystem gets severely compromised. If the project is indeed going to benefit only the rich and has no other benefits for the environment or society at large, it should be cancelled as a policy decision on environmental and social grounds. There should be no ambiguity that protection of environment and continuing welfare of local communities is a much more important priority than developing yet another destination for fun and display of wealth by city-dwellers. It should be noted 


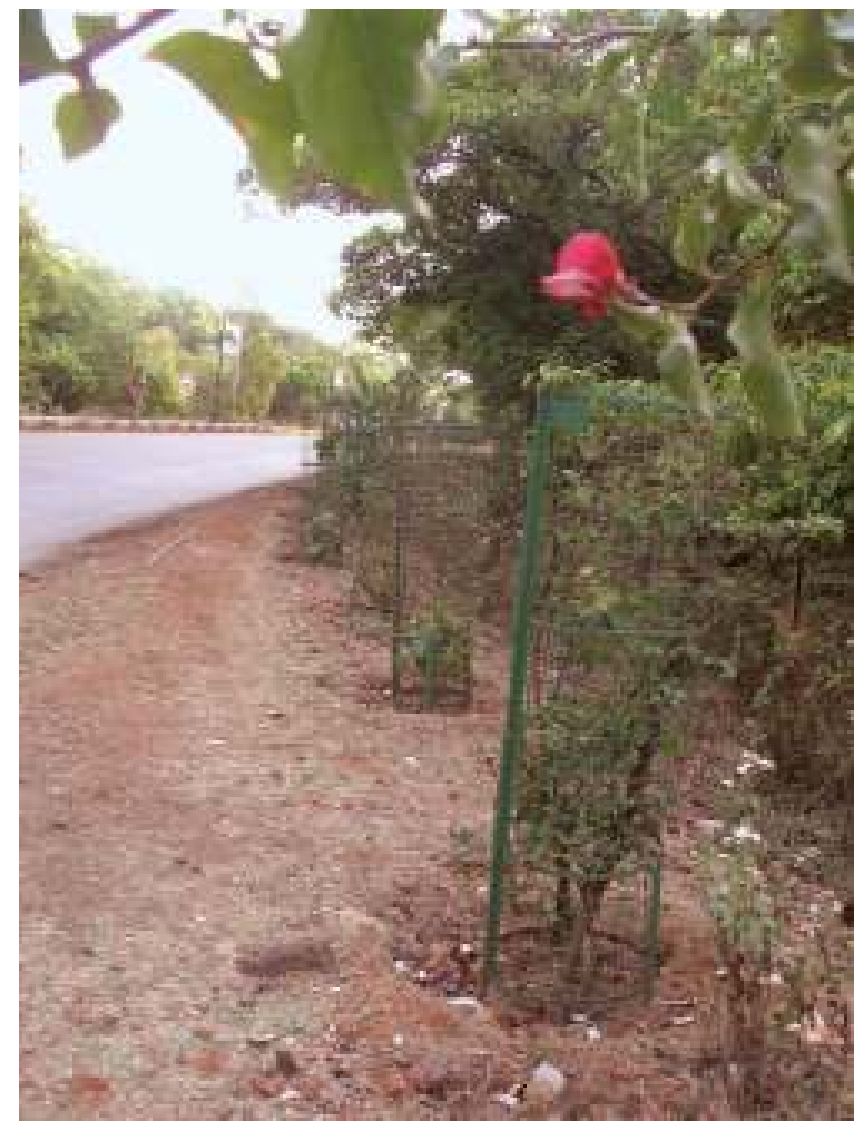

Bouganville plantation at road edges, Mahabaleshwar

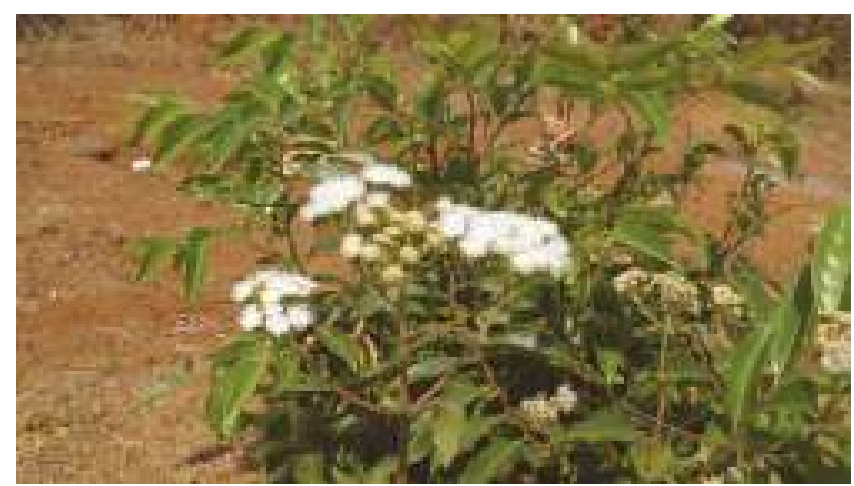

Ageratina adenophora - invasive herb now competes with local vegetation, Mahabaleshwar

here that there are many other forces and reasons that have been causing disturbance to Western Ghats right from local livelihood activities to present marketdriven development. For safeguarding the local environment, different policy approaches can be developed that will ensure environment protection along with the welfare of small local populations that reside in Western Ghats.

Despite such a clear, unambiguous evaluation, if a new hill station project is still approved, a strict planning methodology should be followed to develop the hill station with integration of existing ecological conditions and maintaining or restoring the area as closely as possible to the original working ecosystem.

By referring to the following guidelines, planners can carve out suitable spaces for low scale development expected at any hill station. Here, the ratio of human development i.e. infrastructure with open spaces has to be very low, as this development cannot be like cities where nature is allowed to take a complete backseat. But the settlement has to be surrounded and merged with nature else it can't be called as a hill station.

Suitability matrix: Restrictions for better experience

1. Larger wilderness areas: The ratio of open areas to built-up should be defined. Considering the ecological value of these areas, large proportion of land must be kept inviolate of any developmental activities. As a general guideline, the area under natural forests (if existing or to be developed under project) should be more than $50 \%$ for older destinations and minimum 35 to 45 $\%$ as per the terrain for private projects.

2. Slopes: This is the most important and dominating feature of hilly terrain. The available slope to plain area ratio will determine footprint of human-centric development. Tending slopes in hills is always risky in the long run. For example any ghat road has risks of landslides during monsoon which happens due to instability created by cutting the hill. Even simple leveling of land in sloping, high-rainfall areas creates soil erosion problems. It also disturbs a number of

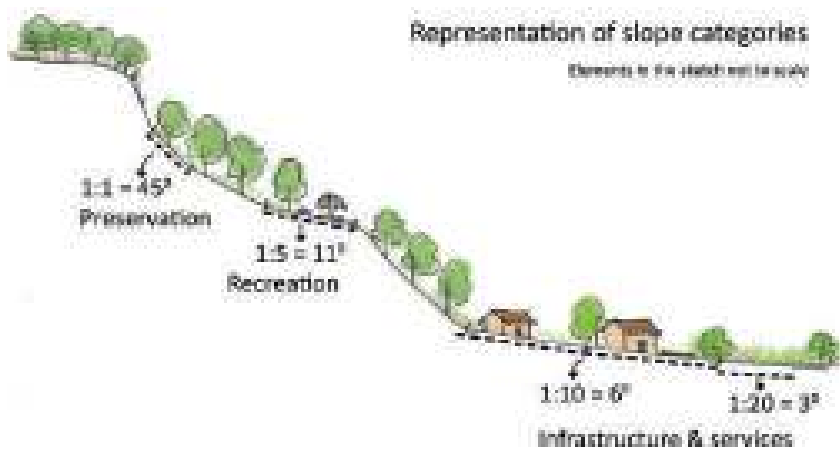

A schematic suggesting ideal land-use for respective slopes 
landscape units creating fragile areas for humans and nature. So any infrastructure development should be planned on slopes from flat land i.e. $0^{0}$ up to a gradient of $6^{0}$ which is a developable slope, ideal for infrastructure like road, construction. Areas other than 0 to 6 degrees of slopes i.e. slopes higher than 6 degrees spread over moderate to steep slopes can be put to uses other than infrastructure. Considering hilly topography, this means that the settlement will happen in lower portions, on flat areas on spur tops and in mountain top plateaus. These areas are small in percentage, which actually suits the kind of development hill stations suggests.

3. Water: Water availability is always low in hills. As the terrain is sloping, water tends to flow to lower parts and there are fewer chances of natural storage. As a strategy, small water holding tanks with decentralized approach should be planned. This will also reduce the impacts of creating huge distribution system on surrounding. Considering all this, the number of units and extent of development will be decided by the available sources and quantity of water. This also means that treatment and recycling of waste water should be of high priority.

4. Landscape units: This dimension is added to planning due to micro features on land.

a. One of the main units is the 'stream network', the drainage pattern of an area. Being a high rainfall region, there are numerous small to large streams that are carriers of fresh water. They become an important feature for both nature and humans. It will be appropriate to say that if streams are managed for nature, they will provide many services to humans like, recharging of water, flood management, and a congenial atmosphere.

b. Second important unit will be 'Areas with special biodiversity'. This could be a single old growth tree, a rare orchid or a patch of dense shrubs or Sacred Groves. They are important to be preserved just for biodiversity value.

c. In some areas there are few special ecosystems like the rocky plateaus (Watve, 2013). Two such popular places are Kaas and Panchgani table land. Both represent this special ecosystem and Panchgani table land has deteriorated due to tourist activities. These are areas of special scientific interests and in need of highlycontrolled tourism which is essential to consider in planning. These areas are flat and could well be considered easy for 'development'. Hence the temptation to build these areas out must be consciously avoided.

d. Scenic View points: They serve as tourist attractions and can be developed carefully without hampering natural beauty. Examples are Arthur's Seat or Lodwick Point at Mahabaleshwar. Many times these points are crowded due to hawkers and illegal stalls owing to short-term commercial gain.

e. One more important unit is agricultural fields. It is known that it takes 500 to 1000 years to form a 1-inch layer of soil. In hilly terrain it is difficult to find cultivable areas with good soil. So, conserving such areas for future food security is wise.

5. Open space management: Treatment of open spaces will decide the aesthetics and overall ambience of the destination. Looking at the ecological needs, all the open spaces should be planned to have maximum tree canopy vegetation, be it a garden in a bungalow or resorts or public gardens.

The above factors will primarily decide the landuse, layout and overall character of the area. Add to this historical and cultural aspect like temples, forts, and old settlements. Their character too will define the overall layout to some extent. This suitability matrix is based on a general understanding, which needs to be made site-specific for each destination with deep understanding of local ecology.

With the above principles driving the base layer of a general zonal plan, further detailed planning should consider the following points :

1. Use of local and eco-friendly technologies which are not intense on the use of electricity or fossil fuels

2. Understanding local needs and providing ways to use natural resources in sustainable way

3. Role of local communities, their traditional wisdom and aspirations

4. Preservation of unique features like springs, ponds, and forts

5. Identification and integration of wildlife needs and their corridors

6. Restoration of denuded areas

7. Architectural character responsive to climate and ecology that facilitates low use of resources

8. Themes, activities and attractions based on nature or selection of amenities that doesn't go against nature 
9. Effective waste management systems

10. Promoting 'near-nature' lifestyle through planning and space utilization

11. Using appropriate techniques for green areas like selection of native plants, energy - resource friendly landscapes, leading chemical free gardens, creating habitats

12. Activities and opportunities for awareness creation for tourists beyond enjoyment

13. Understanding of construction and operational phase, respective activities, their impacts and mitigation measures should reflect in planning

For this type of planning, a team of experts in geology, biology, ecology, biodiversity, GIS, and planning need to come together and conduct an allseasons detailed Ecological Assessment (EA). The EA should include :

1. Assessment of existing natural conditions of hydrology and strata

2. Mapping of resources

3. Detailed survey of biodiversity and its seasonal variations

4. Detailed mapping of biodiversity

5. Identification of special and rare biodiversity with correct locations

6. Integrating survey results to create a map showing natural resources and biodiversity with Landscape Ecological perspective

This final mapping along with the details of the study should be used as a base for all further planning. It is easier and essential to follow such a planning methodology for newly developing destinations. It may also be used suitably for existing hill station destinations to assess what ecological value can still be saved, what type of controls should be introduced on tourism and development, etc. From an ecological balance standpoint, some of the existing hill stations have gone almost beyond repair at present. Matheran and Mahabaleshwar are fortunate to have a strong policy framework but for others like Amboli, the local leadership needs to play a very important role.

\section{Conclusion}

Consideration of ecology in planning all aspects of hill stations through public or private effort, will definitely benefit both development and nature. It will protect a landscape which will be sustainable over the long-term and provide a rich experience to local residents and visitors.
It is necessary to accept that aesthetics is the magnet that attracts visitors to a hill station type destination and will continue to be so. Aesthetics means the beauty of the region with the climate and the ambience it offers as experience. Such aesthetics cannot be developed through manicured gardens, man-made plantations, or typical entertainment concepts. The ambience is easily ruined by haphazard development. Our existing hill stations have been victims of gross negligence towards preservation of landscapes and nature.

Restoring the focus on ecological integrity and aesthetics means change in policies, formulation of new laws and active involvement of the public. It is not necessary to destroy ecology for development but both can go hand-in-hand with thoughtful land use and integrated planning.

\section{List of References}

Apart from following references, this article is also based on author's own experience during last twelve years in ecological land management and providing consultancy for two large scale area development projects, extensive travel in Western Ghats and at hill stations, also as team member for preparing the Environment Conservation Plan for Matheran, and as Member of the Matheran High Level Monitoring Committee (HLMC) for two years.

\section{References}

Badrinath Forest Division. Catchment area treatment and Eco-restoration of Impact area plan, Vishnugad Pipalkoti Hydroelectric project. Badrinath Forest Division, Gopeshwar, Garhwal circle, Uttarakhand.

BVIEER, (October 2010). Current ecological status and identification of potential ecologically sensitive areas in Northern Western Ghats. Pune: Institute of Environment Education and Research.

Census, Retrieved from: Office of the Registrar General and Census Commissioner (Web, 2011)

Ecological Society. (January 2007). Environment Conservation Plan for Matheran. Matheran Bachao Samiti.

Kulkarni \& Buono. (2014). Spring Protection Short Course.

Mcharg, I. (1992). Design with Nature. John Wiley \& Sons, Inc.

MIS. (2002). Report on Tourism and Entertainment. Maharashtra Infrastructure Summit.

Naik, Awasthi, \& Mohan. (2002). Springs in a headwater basin in the Deccan Trap country of the Western Ghats, India. Hydrogeology Journal (2002) 
10:553-565 .

Patwardhan, D. A. Matheran Eco sensitive area: Time to catch a positive spirit ! . RANWA.

Planning Board. (July 1984). Mahabaleshwar Panchgani Regional Plan. Mahabaleshwar - Panchgani Regional Planning Board.

Planning Commission. (April 2008). Report of the Task Group on problems of hilly habitations in areas covered by the Hill Areas Development Programme (HADP) / Western Ghats Development Programme (WGDP). Government of India.

Unwalla \& Samant. A comprehensive Heritage listing proposal for Matheran by Ar Kirtida Unwalla and Ar Suneeta Samant.

Watve, A. (2013). Status review of Rocky plateaus in the northern Western Ghats and Konkan region of Maharashtra, India with recommendations for conservation and management. Journal of Threatened Taxa 5(5): 3935-3962; doi:10.11609/JoTT.o3372.3935-62.

\section{End Notes}

BEAG, (2009). Protection of Green Zone in the Mahableshwar-Panchgani Eco-Sensitive Zone. Ruffords Small Grants.

Dandekar, P. (December 2012). Damning the Western Ghats. Save the Western Ghats Conclave. SANDRP.

Kane, V. (Director). Just another death [Motion Picture].

Kumar, \& Khanna. Globally Threatened Indian Fauna. Zoological Survey of India.

MoEF. (2001, January 17). MahabaleshwarPanchgani ESZ notification. India.

MoEF. (2004, January 16). Matheran ESZ notificaiton - Amendment. India.

MoEF. (2003, February 4). Matheran ESZ notification. India.

WGEEP. (2011). Report of the WGEEP. 